\title{
Carbonaceous aerosols recorded in a southeastern Tibetan glacier: analysis of temporal variations and model estimates of sources and radiative forcing
}

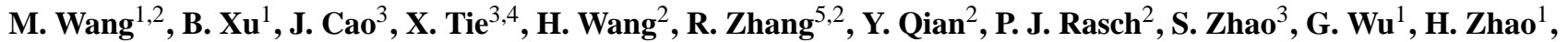 \\ D. R. Joswiak ${ }^{1}$, J. Li $^{1}$, and Y. Xie ${ }^{1}$ \\ ${ }^{1}$ Key Laboratory of Tibetan Environment Changes and Land Surface Processes, Institute of Tibetan Plateau Research, \\ Chinese Academy of Sciences, Beijing 100101, China \\ ${ }^{2}$ Atmospheric Sciences and Global Change Division, Pacific Northwest National Laboratory (PNNL), Richland, WA 99352, \\ USA \\ ${ }^{3}$ State Key Laboratory of Loess and Quaternary Geology, Institute of Earth Environment, Chinese Academy of Sciences, \\ Beijing 100085, China \\ ${ }^{4}$ National Center for Atmospheric Research, Boulder, CO, 80303, USA \\ ${ }^{5}$ Key Laboratory for Semi-Arid Climate Change of the Ministry of Education, College of Atmospheric Sciences, Lanzhou \\ University, Lanzhou 730000, Gansu, China
}

Correspondence to: M. Wang (wangmo@itpcas.ac.cn)

Received: 30 May 2014 - Published in Atmos. Chem. Phys. Discuss.: 31 July 2014

Revised: 17 December 2014 - Accepted: 20 December 2014 - Published: 2 February 2015

\begin{abstract}
High temporal resolution measurements of black carbon (BC) and organic carbon (OC) covering the time period of 1956-2006 in an ice core over the southeastern Tibetan Plateau show a distinct seasonal dependence of $\mathrm{BC}$ and $\mathrm{OC}$ with higher respective concentrations but a lower $\mathrm{OC} / \mathrm{BC}$ ratio in the non-monsoon season than during the summer monsoon. We use a global aerosol-climate model, in which $\mathrm{BC}$ emitted from different source regions can be explicitly tracked, to quantify BC source-receptor relationships between four Asian source regions and the southeastern Tibetan Plateau as a receptor. The model results show that South Asia has the largest contribution to the presentday (1996-2005) mean BC deposition at the ice-core drilling site during the non-monsoon season (October to May) (81\%) and all year round ( $74 \%$ ), followed by East Asia (14\% to the non-monsoon mean and $21 \%$ to the annual mean). The icecore record also indicates stable and relatively low BC and OC deposition fluxes from the late 1950s to 1980, followed by an overall increase to recent years. This trend is consistent with the $\mathrm{BC}$ and $\mathrm{OC}$ emission inventories and the fuel consumption of South Asia (as the primary contributor to annual mean $\mathrm{BC}$ deposition). Moreover, the increasing trend of
\end{abstract}

the OC / BC ratio since the early 1990s indicates a growing contribution of coal combustion and/or biomass burning to the emissions. The estimated radiative forcing induced by BC and OC impurities in snow has increased since 1980, suggesting an increasing potential influence of carbonaceous aerosols on the Tibetan glacier melting and the availability of water resources in the surrounding regions. Our study indicates that more attention to $\mathrm{OC}$ is merited because of its non-negligible light absorption and the recent rapid increases evident in the ice-core record.

\section{Introduction}

Carbonaceous aerosol, released from fossil fuel, biofuel and/or biomass combustion, contains both black carbon (BC, a.k.a. elemental carbon, EC), a strong light absorber, and organic carbon (OC), which also absorbs the near infrared, but more weakly than BC (Kirchstetter et al., 2004; Bond and Bergstrom, 2006). Often mixed with other aerosol species, BC impacts human health, crop yields and regional climate (Auffhammer et al., 2006; Tie et al., 2009), and is believed to 
be the second strongest climate warming forcing agent after carbon dioxide (Jacobson, 2001; IPCC, 2013).

Because of their high population density and relatively low combustion efficiency, developing countries in South and East Asia such as India and China are hotspots of carbonaceous aerosol emissions (Ramanathan and Carmichael, 2008). During the cold and dry winter season, haze (heavily loaded with carbonaceous aerosols) builds up over South Asia, and exerts profound influences on regional radiative forcing (Ramanathan et al., 2007; Ramanathan and Carmichael, 2008), hydrologic cycles (Menon et al., 2002; Ramanathan et al., 2005), and likely Himalaya-Tibetan glacier melting that could be accelerated by the absorption of sunlight induced by $\mathrm{BC}$ in the air and deposited on the ice and snow surfaces (Ramanathan et al., 2007; Hansen and Nazarenko, 2004), although BC deposited in snow and glaciers at some locations may not significantly affect the energy balance (Ming et al., 2013; Kaspari et al., 2014).

Due to the lack of long-term observations of emissions and concentrations of atmospheric carbonaceous aerosols, it is difficult to evaluate the effects of $\mathrm{BC}$ and $\mathrm{OC}$ on historical regional climate and environment before the satellite era. Some studies have evaluated historical anthropogenic emissions based on the consumption of fossil fuels and biofuels (Novakov et al., 2003; Ito and Penner, 2005; Bond et al., 2007; Fernandes et al., 2007). While fossil fuel is the major energy source in the urban areas of South Asia and East Asia, biomass combustion, such as fuel wood, agricultural residue and dung cake, is prevalent in rural areas (Revelle, 1976; Venkataraman et al., 2010; Streets and Waldhoff, 1998). Biomass burning has been considered as the major source of black carbon emissions (Reddy and Venkataraman, 2002; Venkataraman et al., 2005). However, as reliable biomass consumption data are hard to obtain, estimates of $\mathrm{BC}$ and $\mathrm{OC}$ emissions from biomass burning are ambiguous and incomplete.

Measurements of carbonaceous aerosol concentrations in glacier ice are an ideal means of reconstructing historical emissions and revealing long-term trends of anthropogenic aerosol impacts on local climate. Greenland ice-core measurements were previously used to reconstruct the North American $\mathrm{BC}$ emission history and its effects on surface radiative forcing back to the 1880s (McConnell et al., 2007). Himalayan ice cores retrieved from the Tibetan Plateau have revealed the mixed historical emissions from South Asia, Central Asia and the Middle East, and have also been used to evaluate radiative forcing from BC in snow (Ming et al., 2008; Kaspari et al., 2011). Using the Snow, Ice, and Aerosol Radiative (SNICAR) model, Flanner et al. (2007) estimated an instantaneous regional forcing exceeding $20 \mathrm{~W} \mathrm{~m}^{-2}$ by $\mathrm{BC}$ in snow/glaciers over the Tibetan Plateau during the spring season.

By using five ice-core records, $\mathrm{Xu}$ et al. (2009a) elucidated an important contribution of BC to the retreat of Tibetan glaciers in addition to greenhouse gases. Due to the short atmospheric lifetime of carbonaceous aerosols compared to greenhouse gases, emission reductions may be an effective way to mitigate their warming effects. Thus, it is particularly important to identify the source regions and the source types of carbonaceous aerosols observed in Tibetan glaciers. Xu et al. (2009a) suggested that BC deposited on the Tibetan Plateau was broadly from Europe and Asia. However, they did not perform in-depth analysis on emissions from more specific source regions and the source types. In this study, we use the ice core retrieved from the southeastern Tibetan Plateau, also known as the Zuoqiupu ice core in Xu et al. (2009a), to reconstruct the history of atmospheric deposition of carbonaceous aerosols in this glacier, and to characterize emissions and source-receptor relationships with the help of a global climate model in which BC emitted from different source regions can be explicitly tracked. We also estimate the respective contributions from $\mathrm{BC}$ and $\mathrm{OC}$ to radiative forcing in the Zuoqiupu glacier using the ice-core measurements and the SNICAR model.

\section{Methods}

\subsection{Measurements of carbonaceous aerosols in ice cores}

Zuoqiupu glacier is in the southeastern Kangri Karpo Mountains, located on the southeastern margin of the Tibetan Plateau (Fig. 1). In 2007, an ice core of $97 \mathrm{~m}$ in depth $(9.5 \mathrm{~cm}$ in diameter) was retrieved within the accumulation zone of Zuoqiupu glacier at $96.92^{\circ} \mathrm{E}, 29.21^{\circ} \mathrm{N}, 5600 \mathrm{~m}$ a.s.l. The ice core was kept frozen and transported to laboratory facilities at the Institute of Tibetan Plateau Research (Lhasa branch) for analysis. The annual accumulation of snow/ice at the drilling site was around $2 \mathrm{~m}$ on average. The oxygen isotope $\left(\delta^{18} \mathrm{O}\right)$ samples were cut at $10 \mathrm{~cm}$ internals, and $\mathrm{BC}$ and $\mathrm{OC}$ samples at $10-25 \mathrm{~cm}$, resulting in 18 and 9 samples per year on average, respectively. Thus, this ice core provided a high temporal resolution of $\delta^{18} \mathrm{O}$ and $\mathrm{BC}$ and $\mathrm{OC}$ concentrations. $\mathrm{BC}$ and $\mathrm{OC}$ concentrations were measured by using a Desert Research Institute (DRI) Model 2001 thermal/optical carbon analyzer following the IMPROVE TOR protocol (Chow et al., 1993; Chow and Watson 2002; Cao et al., 2008). Note that, according to the thermal/optical measurement method, the analytical result is technically called "EC". Herein we use "BC" to be consistent with the notation in our model simulations and in the literature. The reported OC concentrations from the ice-core measurements can only account for the water-insoluble part of $\mathrm{OC}$ in the ice samples because most of the water-soluble part cannot be captured by the filter-based method applied to liquid samples (melted from the ice). Further details on the analysis methods, ice-core dating and calculation of $\mathrm{BC}$ and $\mathrm{OC}$ seasonal deposition fluxes can be found in Xu et al. (2009a). 


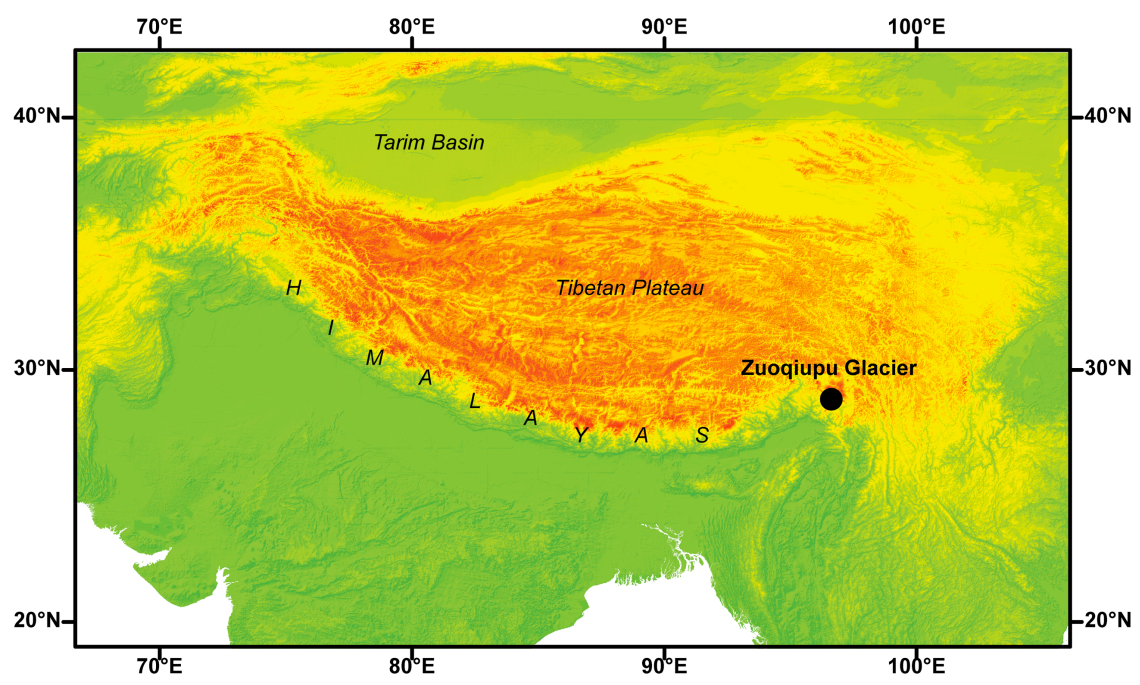

Zuoqiupu Glacier Map

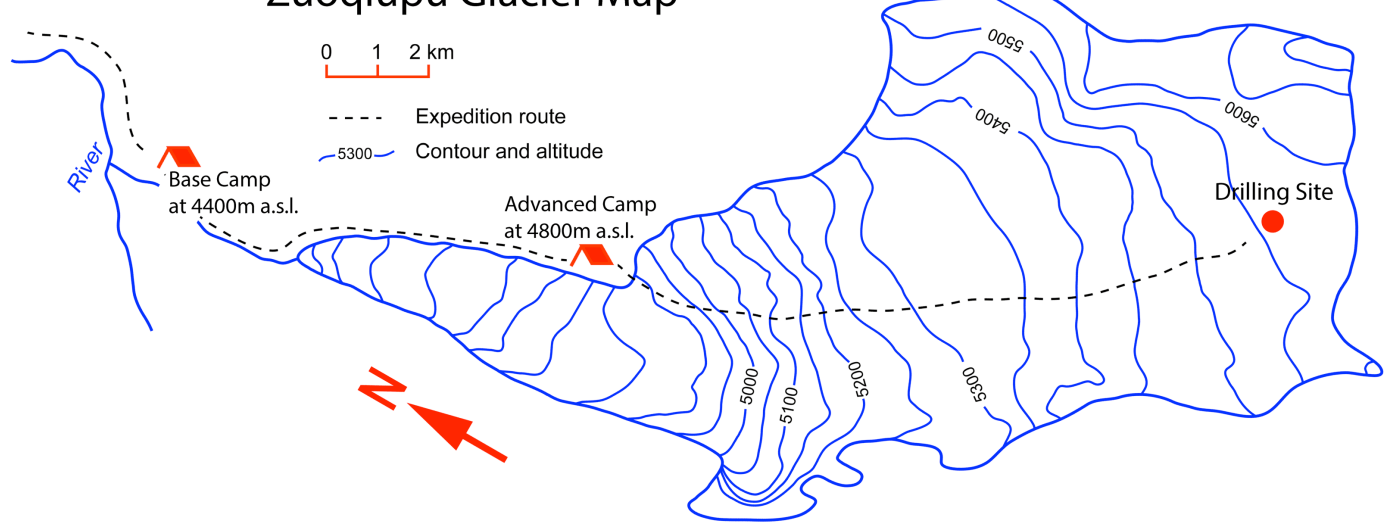

Figure 1. Site location of Zuoqiupu glacier (top): black circle represents the location of Zuoqiupu glacier, and warm colors indicate high elevations over the Tibetan Plateau. Detailed elevation contours of the Zuoqiupu glacier are shown in the bottom panel. Red circle marks the ice-core drilling site.

\subsection{Model and experimental setup}

We use the Community Atmosphere Model version 5 (CAM5; Neale et al., 2012) to help understand the emissions, transport and dry/wet deposition of carbonaceous aerosols in the atmosphere. In the default three-mode modal aerosol scheme of CAM5 used for this study, BC and primary OC are emitted into an accumulation size mode, where they immediately mix with co-existing hygroscopic species such as sulfate and sea salt (Liu et al., 2012). Hygroscopic aerosol particles in the accumulation mode are subject to wet removal by precipitation. Recent model improvements to the representation of aerosol transport and wet removal in CAM5 by $\mathrm{H}$. Wang et al. (2013) have substantially improved the model prediction of global distribution of aerosols, particularly over remote regions away from major sources. To minimize the model biases in simulating meteorological conditions and, particularly, circulations that are critical to aerosol transport, we configure the CAM5 model to run in an of- fline mode (Ma et al., 2013) with wind, temperature, surface fluxes and pressure fields constrained by observations. However, cloud/precipitation fields and interactions between aerosol and clouds are allowed to evolve freely. A source tagging technique has recently been implemented in the CAM5 model to allow for explicit tracking of aerosols emitted from individual source regions and, therefore, to assist in quantitatively characterizing source-receptor relationships (Wang et al., 2014). This tagging technique along with the CAM5 model is used in the present study to do source attribution for carbonaceous aerosols deposited onto the Zuoqiupu glacier.

We conducted an 11-year (1995-2005) CAM5 simulation on a horizontal grid spacing of $1.9^{\circ} \times 2.5^{\circ}$ and 56 vertical levels, with prescribed sea surface temperatures and sea ice distribution. Reanalysis products from NASA's ModernEra Retrospective Analysis for Research and Applications (MERRA) (Rienecker et al., 2011) are used to constrain the meteorological fields of CAM5. For aerosols (includ- 
ing $\mathrm{OC}, \mathrm{BC}$ and other important species), we use the year2000 monthly mean emissions described by Lamarque et al. (2010) that have been used in many global climate models for present-day climate simulations, included in the fifth assessment report (AR5) by the Intergovernmental Panel on Climate Change (IPCC). The monthly mean emissions are repeatedly used for each year in the 11-year simulation. Note that we do not intend to design the model experiment to simulate the whole historical record of $\mathrm{BC}$ in the ice core, but rather for a period of time to demonstrate the impact of meteorology (and the associated transport and removal of aerosols) on the seasonal dependence of $\mathrm{BC}$ deposition in the target region and the lack of a longer-term trend in deposition without considering the temporal variation of emissions.

As the ice-core drilling site was located in a remote and elevated area over the southeastern Tibetan Plateau, local emissions are minimal. Deposition of carbonaceous aerosols is most likely contributed by the non-local major emission sources (e.g., distributions of mean BC emissions during non-monsoon and monsoon seasons shown in Fig. 2) in South Asia and East Asia. These two regions, along with Southeast Asia and Central Asia, are identified as the potential source contributors. Thus, BC emissions from the four regions and the rest of the world are explicitly tracked in the CAM5 simulation.

\section{Results and discussion}

\subsection{Seasonal dependence of carbonaceous aerosols}

$\mathrm{BC}$ and $\mathrm{OC}$ concentrations in the Zuoqiupu ice core both exhibit statistically significant seasonal variations corresponding to the stable oxygen isotope variability, which shows high values during the winter and low values during the summer (Xu et al., 2009a). As shown in Fig. 3, concentrations of $\mathrm{BC}$ and $\mathrm{OC}$ have distinct differences between the summer monsoon and non-monsoon seasons. Seasonally varying emissions and meteorological conditions that determine the transport pathways of BC and OC emitted from major sources, removal during the transport, and local precipitation rate, can cause the seasonal variations of $\mathrm{BC}$ and $\mathrm{OC}$ in ice at the sampling site. The seasonal dependence of $\mathrm{BC}$ and $\mathrm{OC}$ in ice cores is consistent with available observations of atmospheric aerosols on the southern slope of the Himalayas and the southeastern Tibetan Plateau, where the high concentration of carbonaceous aerosols during the cold and dry season suggested an association with the South Asian haze (Cong et al., 2009; Marinoni et al., 2010; Kaspari et al., 2011; S. Zhao et al., 2013; Z. Zhao et al., 2013). The consistency between the seasonal dependence of airborne $\mathrm{BC}$ and OC concentrations and the seasonal variation of ice-core measurements indicates that seasonal differences in precipitation rates at the sampling location are less likely to be the determining factor. Our model results (details discussed in Sect. 3.2) suggest that the seasonal dependence of $\mathrm{BC}$ deposition flux in the target region could be mainly due to meteorological conditions that determine the transport pathways (and associated wet removal processes during the transport). The small seasonal contrasts in BC emissions from the major source regions (see Table 1) that are used in the model simulation do not seem to be able to explain the large seasonal difference in $\mathrm{BC}$ deposition, although the $\mathrm{BC}$ emissions are known to have large uncertainties.

Our further analysis shows that the ratio of $\mathrm{OC}$ to $\mathrm{BC}$ also has clear seasonal dependence. In Fig. 3, the slope of the fitted line to measured $\mathrm{OC}$ vs. BC concentrations during monsoon season is $\sim 6.3$, which is twice the slope for nonmonsoon season $(\sim 3.2)$. The analysis of covariance (ANCOVA) for slope differences of single linear regressions of OC against BC between monsoon and non-monsoon seasons indicates that the seasonal dependence of the relationship between the concentrations of $\mathrm{OC}$ and $\mathrm{BC}$ is significant (at the 0.05 significance level). This also agrees with measurements derived from the ice core drilled from the Palong-Zanbu No. 4 glacier (Xu et al., 2009b) and in atmospheric samples collected from Lulang, southeastern Tibetan Plateau (Z. Zhao et al., 2013). The seasonal dependence of the OC / BC ratio can possibly be derived from the seasonal sources of carbonaceous particles, circulation strength, transport pathways, and/or atmospheric deposition processes. Compared to the respective $\mathrm{BC}$ and $\mathrm{OC}$ concentrations, the seasonal dependence of the $\mathrm{OC} / \mathrm{BC}$ ratio is less straightforward to understand. Circulation patterns together with wet removal processes still determine the transport pathways of emissions from major BC and $\mathrm{OC}$ source regions to the sampling site, which however are less likely to change the OC / BC ratio from certain sources. Therefore, it is more plausible due to seasonally dependent contributions from source regions and/or emission sectors (including fuel types, quantity, and combustion conditions). Cao et al. (2005) found that the average OC / BC ratios measured from plumes of residential biomass burning and coal combustion are substantially higher than from vehicle exhaust. The higher OC / BC ratio during summer monsoon might indicate more contributions from biomass and/or coal burning than fossil fuel combustion.

\subsection{Source attribution}

To attribute the source of $\mathrm{BC}$ at the drilling site (as a receptor region) quantitatively, we use the CAM5 model with the BC source tagging capability to conduct an 11-year simulation, with the last 10 years (1996-2005) used for analysis. The surrounding area is divided into four source regions (see Table 1 and Fig. 4): South Asia, East Asia, Southeast Asia and Central Asia. BC emissions from each of the four regions and the rest of the world are explicitly tracked, so that the fractional contributions by emissions from the individual source regions to $\mathrm{BC}$ deposition in the receptor region can be explic- 
a) Monsoon

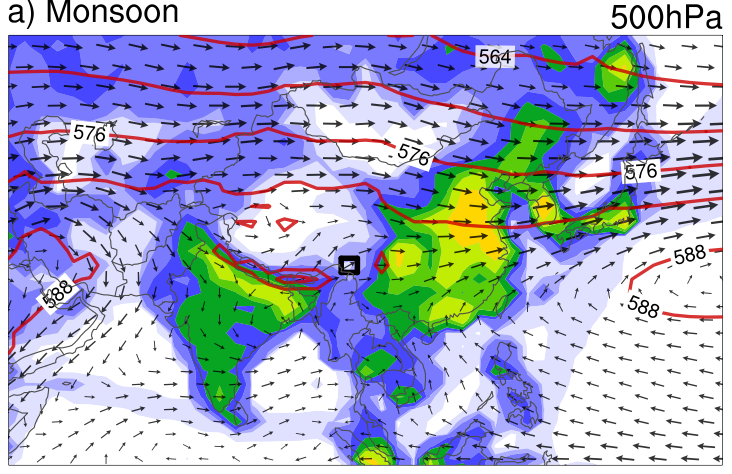

c) Monsoon

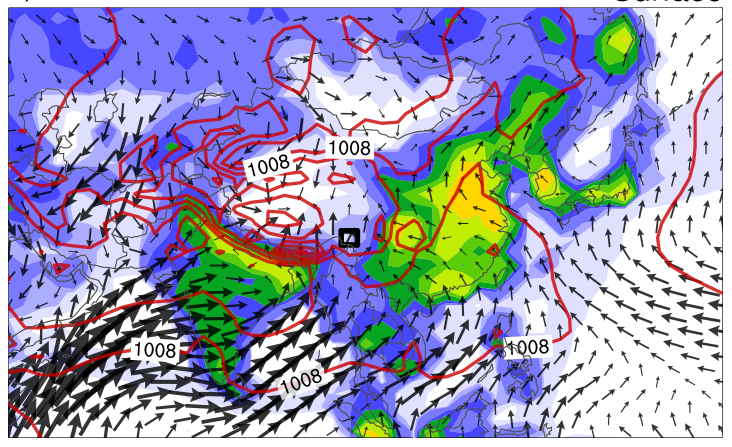

b) Non-monsoon

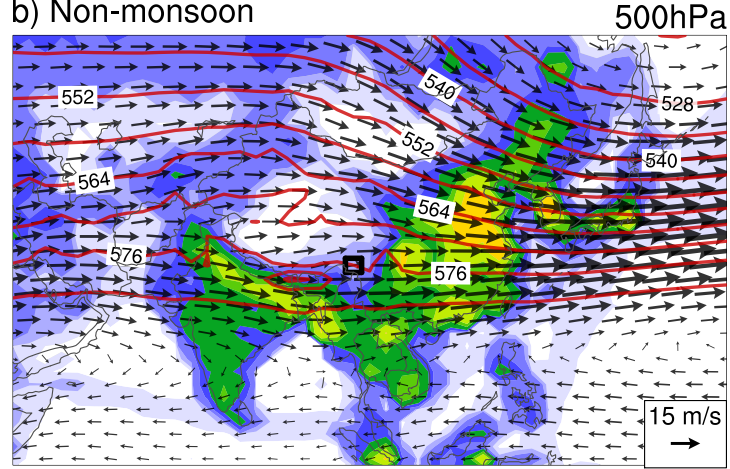

d) Non-monsoon

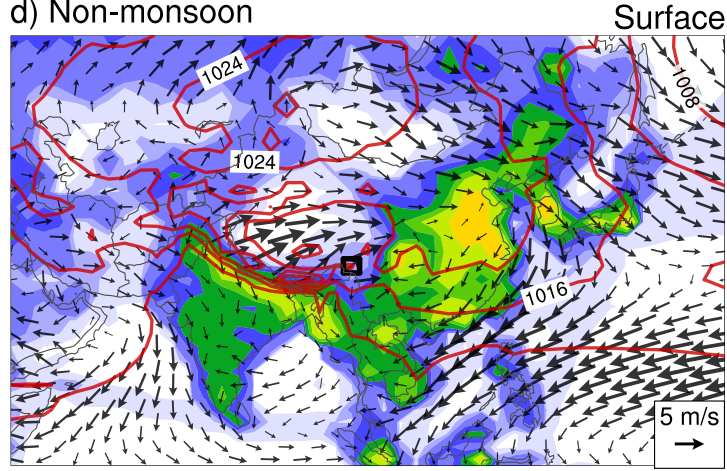

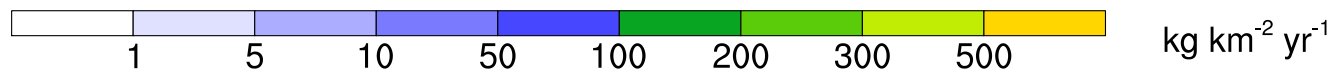

Figure 2. 10-year (1996-2005) mean wind vectors (denoted by arrows) at $500 \mathrm{hPa}$ (a, b) and the surface (c, d) during the summer monsoon (June-September; (a, c)) and non-monsoon seasons, October-May, (b, d) from MERRA reanalysis data sets used to drive the CAM5 simulation. $500 \mathrm{hPa}$ geopotential height (units: $10 \mathrm{~m}$ ) contours with an interval of $60 \mathrm{~m}$ and mean sea-level pressure (units: hPa) contours with an interval of $4 \mathrm{hPa}$ are superimposed on panels $(\mathbf{a}, \mathbf{b})$ and $(\mathbf{c}, \mathbf{d})$, respectively. The background colors show mean BC emission rates based on the IPCC present-day scenario for the corresponding months. The small black box marks the model grid cell in which the ice-core drilling site resides.

Table 1. Source regions (South Asia, East Asia, Southeast Asia, and Central Asia) and corresponding monthly mean BC emissions $\left(\mathrm{Tg} \mathrm{a}^{-1}\right.$ ) and fractional contributions (\%) to BC deposition flux at the Zuoqiupu site in monsoon (June-September), non-monsoon (October-May), and all months during 1996-2005.

\begin{tabular}{|c|c|c|c|c|c|c|c|c|}
\hline \multirow[t]{2}{*}{ Source regions } & \multirow[t]{2}{*}{ Latitude } & \multirow[t]{2}{*}{ Longitude } & \multicolumn{2}{|c|}{ Monsoon } & \multicolumn{2}{|c|}{ Non-monsoon } & \multicolumn{2}{|c|}{ Annual } \\
\hline & & & Contribution & Emission & Contribution & Emission & Contribution & Emission \\
\hline South Asia & $5-35^{\circ} \mathrm{N}$ & $50-95^{\circ} \mathrm{E}$ & 38.51 & 0.65 & 81.26 & 0.74 & 74.48 & 0.71 \\
\hline East Asia & $15-50^{\circ} \mathrm{N}$ & $95-150^{\circ} \mathrm{E}$ & 56.24 & 1.75 & 13.91 & 1.90 & 20.66 & 1.85 \\
\hline Southeast Asia & $0-15^{\circ} \mathrm{N}$ & $95-130^{\circ} \mathrm{E}$ & 0.05 & 0.28 & 0.16 & 0.33 & 0.15 & 0.31 \\
\hline Central Asia & $35-50^{\circ} \mathrm{N}$ & $50-95^{\circ} \mathrm{E}$ & 2.62 & 0.11 & 0.86 & 0.09 & 1.14 & 0.10 \\
\hline
\end{tabular}

itly calculated. Figure 4 shows the spatial distribution of fractional contribution from the four source regions. BC deposition at the drilling site (indicated by the black box in Fig. 4), which has a consistent seasonal dependence (i.e., more during the non-monsoon season; Fig. 5) with ice-core measurements, is predominately (over 95\%) from South Asia and East Asia. The seasonal dependence of $\mathrm{BC}$ deposition is also consistent with a recent regional climate modeling study on
BC deposition on the Himalayan snow cover from 1998 to 2008 (Ménégoz et al., 2014).

The 10-year (1996-2005) average wind fields (at the surface and $500 \mathrm{hPa}$ from MERRA reanalysis data sets), as shown in Fig. 2, indicate distinct circulation patterns during the summer monsoon (June-September) and non-monsoon (October-May) seasons, which in part determine the seasonal dependence of transport of aerosols emitted from the 


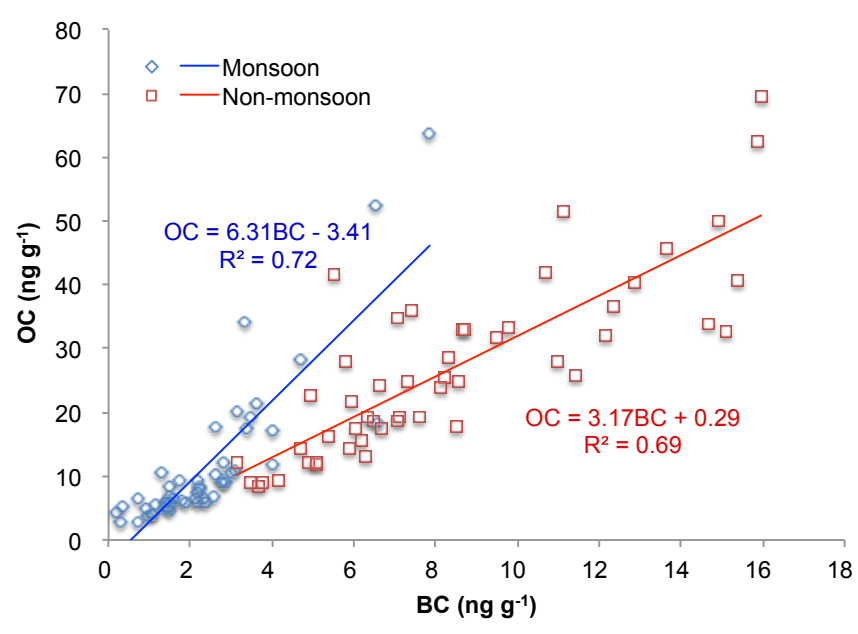

Figure 3. Scatterplots for yearly monsoon and non-monsoon mean OC and BC concentrations during 1956-2006, obtained from the ice-core measurements, and corresponding linear regressions.

different major sources. During the non-monsoon season, a strong westerly dominates the transport from west to east at all levels. Emissions from northern India and Central Asia can have an influence on $\mathrm{BC}$ in the direct downwind receptor region over the southeastern Tibetan Plateau. During the summer monsoon season, the westerly moves northward, and the monsoon flow from the Bay of Bengal at the surface and middle levels (e.g., $500 \mathrm{hPa}$ ), coupled with the monsoon from the Indochina peninsula and the South China Sea, exert an influence on $\mathrm{BC}$ in the receptor area. The strong monsoon precipitation removes $\mathrm{BC}$ from the atmosphere during the transport. The high Himalayas can partly block the further transport of emissions from South Asia to the Tibetan Plateau, although small local topographical features such as the Yarlung Tsangpo River valley can provide a gate for the pollution to enter the inner Tibetan Plateau (Cao et al., 2010). Elevated emissions from the west (or the northern part of South Asia) can take the pathways at middle and upper levels, but they have minimal contribution to deposition. Therefore, BC emissions from East Asia play a relatively more important role in affecting deposition at the Zuoqiupu site during the monsoon season.

The fractional contributions to 10 -year mean BC deposition at the drilling site from the four tagged regions are summarized in Table 1. Results show that South Asia is the dominant contributor $(\sim 81 \%)$ during the non-monsoon season with $\sim 14 \%$ from East Asia, while the contribution of East Asia $(\sim 56 \%)$ is larger than that of South Asia $(\sim 39 \%)$ during the monsoon season. For the annual mean BC deposition, South Asia ( $\sim 75 \%)$ is the biggest contributor, followed by East Asia $(\sim 21 \%)$. Emissions from the Central Asia and Southeast Asia regions have much smaller contributions $(<3 \%)$ for all seasons. These results agree well with the short-term source attribution study by Lu et al. (2012) using the Hybrid Single-Particle Lagrangian Integrated Trajectory (HYSPLIT) model.

For comparison, seasonal and annual mean BC emissions from the individual tagged source regions are also included in Table 1. Apparently, the contrast in strengths of regional emissions alone cannot explain their relative contributions to $\mathrm{BC}$ deposition at the sampling site, and the small seasonal variations in emissions are unlikely to be the cause of seasonal dependence of source attribution. Note that the BC emission inventory (Lamarque et al., 2010) used in CAM5 does not consider seasonal variations in anthropogenic emissions, which is likely to have introduced biases in the quantitative model estimates of seasonal dependence of contributions, but the relative importance of source regions should be robust.

\subsection{Interannual variations and long-term trend}

Based on annual snow accumulation and BC and OC concentrations derived from the ice-core record, the annual $\mathrm{BC}$ and OC deposition fluxes can be estimated, which are then used to examine the interannual variations and long-term trend in the fluxes and the ratio of $\mathrm{OC} / \mathrm{BC}$, as well as the relationship with emissions from the major contributor. As illustrated in Fig. 6, from the late 1950s to 1980, the BC and OC fluxes in the Zuoqiupu ice core are relatively low and stable in comparison to those after 1980. During the period 1956 to 1979 , average fluxes are 9.1 and $28.7 \mathrm{mg} \mathrm{m}^{-2} \mathrm{a}^{-1}$ for BC and $\mathrm{OC}$, respectively. Both $\mathrm{BC}$ and $\mathrm{OC}$ fluxes began to show increasing trends from the early 1980s. These trends continued in the early 1990s, but started to drop in the mid-1990s, reaching a minimum in 2002 followed by a rapid increase. In 2006, BC and OC fluxes are 19.2 and $93.9 \mathrm{mg} \mathrm{m}^{-2} \mathrm{a}^{-1}$, respectively, which are 2 and 3 times the respective average fluxes before 1980. The 5-year average OC / BC flux ratio is steady before 1990; however, it shows a continual increase afterwards and has been higher than the average value (3.2) for the period of 1956-1979 since the mid-1990s (Fig. 6). The 10-year CAM5 model simulation, in which annual emissions are fixed but meteorological conditions vary, shows no increasing trend in $\mathrm{BC}$ and $\mathrm{OC}$ deposition fluxes (BC deposition shown in Fig. 5), indicating that the increasing trend seen in the observations was not due to changes in meteorology.

As shown in the CAM5 model simulation, the annual mean atmospheric deposition of $\mathrm{BC}$ over the southeastern Tibetan Plateau is mostly contributed by emissions from South Asia, particularly in the non-monsoon season. The BC and OC deposition fluxes derived from the ice-core measurements may reflect changes in South Asian emissions to some extent. The temporal variations of $\mathrm{BC}$ and $\mathrm{OC}$ deposition fluxes (see Fig. 6) are compared with the primary BC and OC emissions from fossil fuel and biofuel combustion in South Asia during 1955-2000 (Bond et al., 2007). BC and OC emissions during 1996-2010 from $\mathrm{Lu}$ et al. (2011) are 


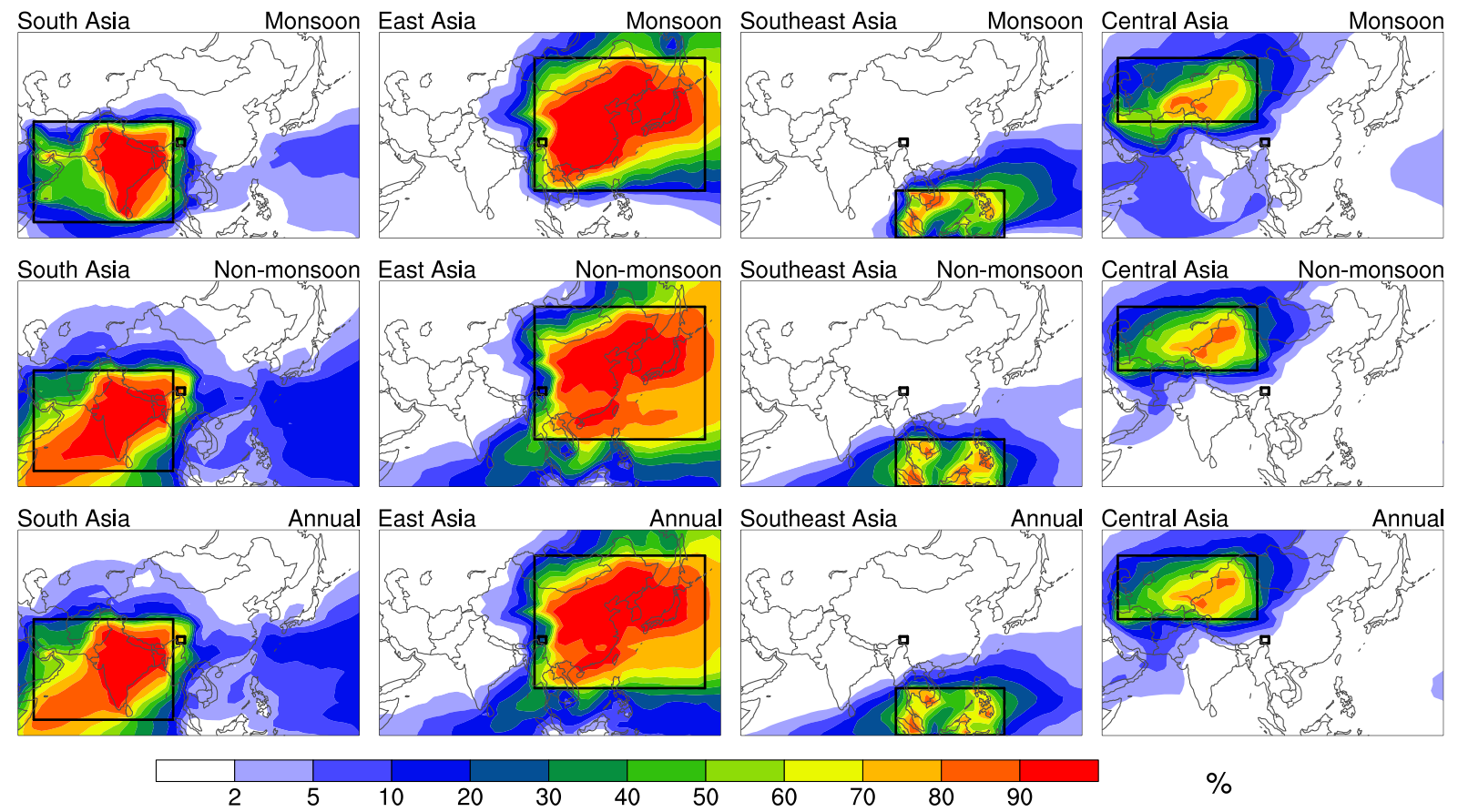

Figure 4. Spatial distributions of fractional contribution from the four source regions (South Asia, East Asia, Southeast Asia, and Central Asia) to monsoon, non-monsoon, and annual mean BC deposition fluxes during 1996-2005. The large black boxes indicate the boundary of source regions, and the small black box marks the model grid cell where the Zuoqiupu drilling site is located. Color in the small black box in each panel corresponds to the fraction contribution to $\mathrm{BC}$ deposition at the sampling site. Exact percentage contributions are provided in Table 1.

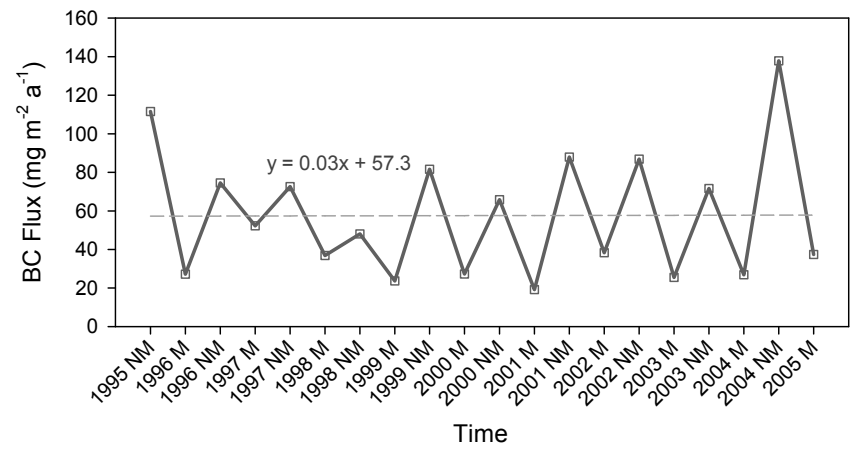

Figure 5. Seasonal dependence ("NM" for non-monsoon season and " $\mathrm{M}$ " for monsoon season) of BC deposition flux at the Zuoqiupu site from 1995 to 2005 simulated in CAM5. The dashed line represents a linear regression of all data points.

also illustrated in Fig. 6 to extend the emission data to cover the entire time period that the ice-core data span. Note that the emission data from Lu et al. (2011) are only for India, which is the largest energy consumer and carbonaceous aerosol-emitting country in South Asia. There are differences between the emissions of Bond et al. (2007) and $\mathrm{Lu}$ et al. (2011) during the overlap time period (1996-2000). However, good agreements on the increasing trend can be found in the respective deposition fluxes and emissions of $\mathrm{BC}$ and
OC (Fig. 6). The OC / BC emission ratio also shows an increasing trend from the late 1990s to 2003, which is consistent with that of the $\mathrm{OC} / \mathrm{BC}$ ratio in the ice-core record. The annual mean aerosol index over industrial and populated cities in the northern part of India increased from 1982 to 1993 and more significantly from 2000 to 2003 (Sarka et al., 2006). This trend is similar to that of carbonaceous aerosols in the ice-core record, and it might indicate a causal relationship between BC and OC over the southeastern Tibetan Plateau and emissions from the northern part of South Asia.

\subsection{Emission source analyses}

$\mathrm{BC}$ and $\mathrm{OC}$ in the atmosphere are co-emitted from a variety of natural and anthropogenic sources, including combustion of fossil fuel, biofuel and/or biomass burning. In general, open biomass burning typically produces more abundant OC (i.e., a larger OC / BC ratio) compared to fossil fuel combustion due to a lower process temperature (Ducret and Cachier, 1992). The OC / BC ratio has often been used to discriminate fossil fuel combustion and biomass burning emissions as the source for particles in the atmosphere and in precipitation (Novakov et al., 2000; Stone et al., 2007; Ducret and Cachier, 1992; Xu et al., 2009b). For example, Cao et al. (2005) collected particulate matter samples from the plumes of residential biomass burning, coal combustion, and motor-vehicle 

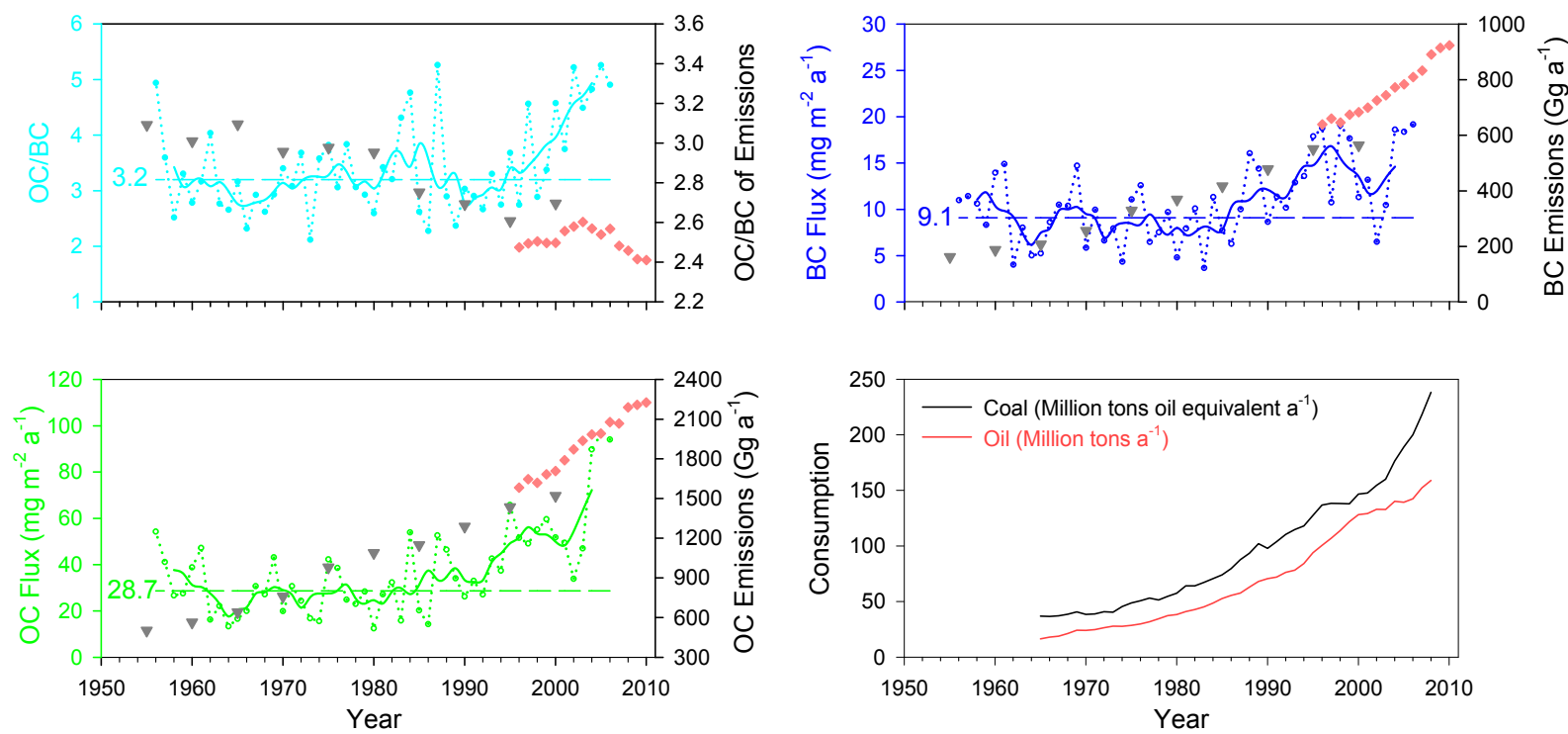

Figure 6. Time series of annual (dotted line with circles) and 5-year averaged (solid line) OC / BC ratios (top left), BC (top right) and OC deposition fluxes (bottom left) based on the Zuoqiupu ice-core measurements for the time period of 1956-2006. The average values of the OC / BC ratio, BC and OC during 1956-1979 are marked by dashed lines. BC and OC emissions in South Asia (Bond et al., 2007) and the corresponding OC / BC emission ratios are illustrated with gray triangles, and with red diamonds for emissions in India (Lu et al., 2011). Coal and oil consumption data are shown in the bottom-right panel (BP Group, 2009).

exhaust sources, and analyzed OC and BC with a DRI thermal/optical carbon analyzer (Model 2001). They reported average $\mathrm{OC} / \mathrm{BC}$ ratios of $60.3,12.0$, and 4.1 for biomass burning, coal combustion and vehicle exhaust, respectively. The increasing $\mathrm{OC} / \mathrm{BC}$ ratios based on the ice-core measurements since the early 1990s (Fig. 6) suggest expanded coal consumption and/or usage of biomass fuel, although the ratios might have been underestimated, because water-soluble OC was not captured in the sample analyses. However, such bias would have occurred in all the samples and had little impact on the trend, unless including water-soluble OC could dominate the temporal variation of the $\mathrm{OC} / \mathrm{BC}$ ratio. Otherwise, our results indicate that the relative contribution of coal combustion and biomass burning to the carbonaceous particles deposited into the ice core in the southeastern Tibetan Plateau has been increasing faster than the contribution of fossil fuel combustion since the early 1990s. Improved combustion technologies may have reduced both $\mathrm{BC}$ and $\mathrm{OC}$ emissions from the combustion of the same amount of fuels, but the influence on the OC / BC ratio is unclear. Presumably, improved combustion technologies after 1990 in South and East Asia did not dominate the $\mathrm{OC} / \mathrm{BC}$ ratio.

The temporal variations of $\mathrm{BC}$ and $\mathrm{OC}$ in the Zuoqiupu ice core, along with the source attribution analysis of the CAM5 model results, suggest an increasing trend in emissions and altered emission sources in South Asia during the late twentieth century. Coal has been the primary energy source in South Asia. For example, in India, coal accounted for $41 \%$ of the total primary energy demand in 2007 , followed by biomass (27\%) and oil (24\%) (IEA, 2009). The consumption data of coal and crude oil in South Asia (BP Group, 2009 ) is compared with the BC and OC fluxes in Fig. 6 (bottom right). Coal consumption had an increasing trend from 1965 to 2008 , particularly in the two time periods $1980-1995$ and 2003-2008 after a leveling off during 1996-2002. This trend is consistent with the variations of $\mathrm{BC}$ and $\mathrm{OC}$ deposition fluxes in the Zuoqiupu ice core. The correlations between coal consumption and $\mathrm{BC}\left(R^{2}=0.43, p<0.001\right)$ and OC $\left(R^{2}=0.62, p<0.001\right)$ in the ice core are both statistically significant. The oil consumption had a comparable increasing trend as coal before it slowed down during 2000 2006.

Biomass is the second largest energy resource in South Asia, and it is essential in rural areas. In India, $70 \%$ of the population lives in rural areas, and depends substantially on solid fuels (i.e., firewood, animal dung, and agriculture residues) for cooking and heating (Heltberg et al., 2000). Even in urban areas, biomass contributes $27 \%$ of the household cooking fuel (Venkataraman et al., 2010). Although the consumption of biomass is lower than coal, the $\mathrm{OC} / \mathrm{BC}$ emission ratio for biomass burning is much higher than from coal combustion (60.3 vs. 12.0) (Cao et al., 2005). The BC emission factor for biomass burning (varying from $0.48 \pm 0.18 \mathrm{~g} \mathrm{~kg}^{-1}$ for savanna and grassland burning to $1.5 \mathrm{~g} \mathrm{~kg}^{-1}$ for charcoal burning) is also generally higher than that for coal $\left(0.2 \mathrm{~g} \mathrm{~kg}^{-1}\right.$ for most combustion conditions) and oil combustion $\left(0.3 \mathrm{~g} \mathrm{~kg}^{-1}\right.$ on average, varying from $0.08 \mathrm{~g} \mathrm{~kg}^{-1}$ for heavy fuel oil to $0.66 \mathrm{~g} \mathrm{~kg}^{-1}$ 
for diesel) (Andreae and Merlet, 2001; Bond et al., 2004, 2007). Therefore, it is very likely that the OC / BC ratio of atmospheric carbonaceous aerosols and in the ice-core samples (Fig. 6) was dominated by biomass burning emissions. Previous studies have concluded that carbonaceous aerosol emissions from biomass burning are the largest source in South Asia (Venkataraman et al., 2005; Gustafsson et al., 2009). A general increase in energy-intensive lifestyles associated with the accelerated growth of population and economy put pressure on energy resources, and induced energy transitions and the use of non-sustainable biomass in South Asia (Sathaye and Tyler, 1991; Pachauri, 2004; Fernandes et al., 2007). For instance, biofuel consumption in South Asia increased by $21 \%$ per decade on average during 1950-2000 (Bond et al., 2007; Fernandes et al., 2007). In addition, fuel wood, a more desirable biofuel option, contributed $68 \%$ in 1978 to total energy demand by rural populations in India, and increased to $78 \%$ in 2000 (Fernandes et al., 2007).

\subsection{Radiative forcing induced by carbonaceous aerosols in Tibetan glaciers}

$\mathrm{BC}$ is often the most important light-absorbing impurity in surface snow because of its strong absorption of solar radiation. The effect of BC in snow on surface albedo reduction and the resultant positive radiative forcing have been widely addressed and reported (e.g., Warren and Wiscombe, 1980; Clarke and Noone, 1985; Hansen and Nazarenko, 2004; Hadley and Kirchstetter, 2012; Flanner et al., 2007; 2009; McConnell et al., 2007; Ming et al., 2008; Kaspari et al., 2011; Qian et al., 2011, 2014, 2015). In contrast, the impact of OC in snow has not been widely assessed because of its relatively weak light absorption over the entire spectrum compared to $\mathrm{BC}$, and because of large uncertainties associated with OC light-absorbing properties and measurements of OC in snow. However, there has been increasing interest in light-absorbing OC (a.k.a. brown carbon) and its radiative effect in both the atmosphere and snow. A growing number of studies (e.g., Kirchstetter et al., 2004; Andreae and Gelencsér, 2006; Hoffer et al., 2006; Yang et al., 2009; Kirchstetter and Thatcher, 2012) have reported that airborne brown carbon can contribute significantly to aerosol light absorption in the atmosphere, although there are still substantial uncertainties in quantifying optical properties of brown carbon, which makes the model estimation of OC radiative forcing difficult. Similarly, the importance of OC absorption in snow has been recognized and suggested for inclusion in modeling aerosol snow-albedo effects (e.g., Flanner et al., 2009; Aoki et al., 2011). Observational analysis of light-absorbing particles in Arctic snow reported that the main non-BC component is brown carbon, which accounted for $20-50 \%$ of the visible and ultraviolet absorption (Hegg et al., 2009, 2010; Doherty et al., 2010). In the rural area of central northern China, brown carbon in winter snow also played an important role in visible light absorption, which contributed about
$60 \%$ to light absorption at $450 \mathrm{~nm}$ and about $40 \%$ at $600 \mathrm{~nm}$ (X. Wang et al., 2013). A more recent observational study by Dang and Hegg (2014) quantified the light absorption by different light-absorbing particulates in snow, and suggested that humic-like substances and polar OC contributed 9 and $4 \%$ to the total light absorption, respectively. Despite the substantial uncertainties in brown carbon optical properties, a recent global modeling study (Lin et al., 2014), in which a range of optical properties of brown carbon taken from the literature were applied to OC-in-snow concentrations simulated in a global chemical transport model, showed that the global OC forcing in land snow and sea ice is up to $24 \%$ of that caused by BC. Thus, the contribution of OC in snow to the surface albedo reduction is likely to be important, which has also been considered in recent climate modeling studies (Qian et al., 2015).

In this study, we use the SNICAR online model (available at http://snow.engin.umich.edu/; Flanner et al., 2007) to estimate radiative forcing induced by the observed $\mathrm{BC}$ as if they were present in snow. A detailed description of the SNICAR model has been documented by Flanner and Zender (2005, 2006) and Flanner et al. (2007). Here we only briefly describe the setup of input parameters required for running the SNICAR model. A mass absorption cross section (MAC) of $7.5 \mathrm{~m}^{2} \mathrm{~g}^{-1}$ at $550 \mathrm{~nm}$ for uncoated BC particles (Bond and Bergstrom, 2006) is assumed to be same as the default value, and thus one of the input parameters for adjusting the MAC value in the online SNICAR model, the MAC scaling factor, is set to 1. According to the previous studies (Cuffey and Paterson, 2010; Wiscombe and Warren 1980) and measurements in the Qiyi glacier and the Zuoqiupu glacier, an effective radius of $100 \mu \mathrm{m}$ with a density of $60 \mathrm{~kg} \mathrm{~m}^{-3}$ for new snow, and an effective radius of $400 \mu \mathrm{m}$ with a density of $400 \mathrm{~kg} \mathrm{~m}^{-3}$ for aged snow, are adopted for the forcing calculation. As we focus on the estimation of radiative forcing by carbonaceous particles, other impurity contents, such as dust and volcanic ash, are set to zero. The annual mean BC concentration during 1956-1979 was $4.4 \mathrm{ng} \mathrm{g}^{-1}$, and increased to $12.5 \mathrm{ng} \mathrm{g}^{-1}$ in 2006 . As a consequence, the annual mean radiative forcing induced by $\mathrm{BC}$ in snow, as calculated by the SNICAR model, nearly proportionally increases from 0.75 to $1.95 \mathrm{~W} \mathrm{~m}^{-2}$. Our estimate of mean $\mathrm{BC}$ forcing is lower than the estimated Eurasian radiative forcing $\left(2.7 \mathrm{~W} \mathrm{~m}^{-2}\right)$ in spring (Flanner et al., 2009), but it is comparable to that in the East Rongbuk glacier over the Himalayas, which was in the range of $1-2 \mathrm{~W} \mathrm{~m}^{-2}$ (Ming et al., 2008). Kaspari et al. (2009) reported a threefold increase in radiative forcing from $\mathrm{BC}$ in snow over the Himalayas after 1975, which is consistent with the increasing trend in our results.

The SNICAR model currently does not support the calculation of OC-in-snow forcing in the same way as that for $\mathrm{BC}$ due to a lack of reliable OC optical properties that span the dimensions of snow grain size and OC particle size (M. Flanner, personal communication, 2014). We take a MAC value of $0.6 \mathrm{~m}^{2} \mathrm{~g}^{-1}$ at $550 \mathrm{~nm}$ for OC (Kirchstet- 
ter et al., 2004), and assume a constant factor of 0.08 (i.e., 0.6/7.5) to scale down MAC values of $\mathrm{BC}$ at all wavelengths to obtain a first-order guess of OC-in-snow forcing using SNICAR. The estimated OC forcing has a fourfold increase from $0.2 \mathrm{~W} \mathrm{~m}^{-2}$ (for a mean $\mathrm{OC}$ concentration of $13.8 \mathrm{ng} \mathrm{g}^{-1}$ during 1956-1979) to $0.84 \mathrm{~W} \mathrm{~m}^{-2}$ (for a mean OC concentration of $61.3 \mathrm{ng} \mathrm{g}^{-1}$ in 2006), which are 27 and $43 \%$ of the corresponding BC-in-snow forcing, respectively. The $\mathrm{OC} / \mathrm{BC}$ forcing ratios based on our simple guesses are larger than the upper bound of the estimates (i.e., $24 \%$ ) by Lin et al. (2014).

Two main assumptions could have caused our first-order estimate of $\mathrm{OC}$ forcing to have large biases. First, the MAC value of $0.6 \mathrm{~m}^{2} \mathrm{~g}^{-1}$ (at $550 \mathrm{~nm}$ ) was based on OC extracted from biomass burning samples that tends to have a higher absorption efficiency than OC emitted from fossil fuel combustion (Kirchstetter et al., 2004). This may cause an overestimation of OC forcing. Second, we treated all the water-insoluble OC from the ice-core measurements as lightabsorbing brown carbon in the forcing estimation, which also likely results in an overestimation of $\mathrm{OC}$ forcing if a significant fraction of $\mathrm{OC}$ is non-absorbing. However, the watersoluble part, accounting for about half of OC observed in the Manora peak and northwestern India (Ram et al., 2010; Rajput et al., 2014), can also contribute to some absorption of UV and visible light (Chen and Bond, 2010; Beine et al., 2011). Thus, the absorption by water-soluble OC that was not included in the forcing estimate may compensate for the high bias to some extent. According to a laboratory study by Chen and Bond (2010), a large fraction of absorbing OC from hard wood burning is water-insoluble. As water-insoluble OC recorded in the ice core herein was very likely dominated by biomass burning emissions (Sect. 3.4), the second assumption we used here may not cause a huge bias in estimating $\mathrm{OC}$ forcing in snow.

It is also important to note that we did not consider variations in chemical compounds of $\mathrm{OC}$, the changes in OC during sample filtration, and the different spectral dependence of $\mathrm{OC}$ and $\mathrm{BC}$ absorption. Although such uncertainties can also cause bias in the estimation of OC radiative forcing herein, the increasing trend should be robust.

$\mathrm{BC}$ and $\mathrm{OC}$ concentrations in the ice core increased rapidly after 1980, and the induced radiative forcing rose as a consequence. According to the estimates using the SNICAR model, the average $\mathrm{BC}$ radiative forcing had increased $43 \%$ after 1980, and OC radiative forcing had an increase of $70 \%$. These numbers are by no means accurate, but the stronger increasing trend in the ice-core recorded $\mathrm{OC}$ than in $\mathrm{BC}$ during 1990-2006 (Fig. 6) suggests that the contribution of OC to the total radiative forcing in the glacier induced by snow/ice impurities deserves more attention.

\section{Summary and conclusions}

Light-absorbing carbonaceous aerosols can induce significant warming in the atmosphere and in snow and glaciers, which likely accelerates the melting of glaciers over the Himalayas and the Tibetan Plateau. Ice-core measurement of carbonaceous aerosols is a useful mechanism for evaluating historical emission inventories and revealing longterm changes in anthropogenic aerosols and their impacts on regional climate. In this study, we analyze carbonaceous aerosols recorded in an ice core $(97 \mathrm{~m}$ in depth and $9.5 \mathrm{~cm}$ in diameter) retrieved from the Zuoqiupu glacier $\left(96.92^{\circ} \mathrm{E}\right.$, $29.21^{\circ} \mathrm{N}, 5600 \mathrm{~m}$ above sea level) in the southeastern Tibetan Plateau for their seasonal dependence and long-term trend. The glacier has a unique geographical location that is in close proximity to major Asian emission sources. With the help of a global climate model (CAM5) in which black carbon (BC) emitted from different source regions can be explicitly tracked, we are able to characterize BC sourcereceptor relationships between four Asian source regions (i.e., South Asia, East Asia, Southeast Asia and Central Asia) and the Zuoqiupu glacier area as a receptor. We also estimate the radiative forcing in snow due to $\mathrm{BC}$ and $\mathrm{OC}$ using the ice-core measurements and an offline snow-ice-aerosolradiation model (called SNICAR).

$\mathrm{BC}$ and $\mathrm{OC}$ concentrations in small segments of the Zuoqiupu ice core were measured using a thermal-optical method. Ice-core dating based on significant seasonal variations of oxygen isotope ratios $\left(\delta^{18} \mathrm{O}\right)$ was used to construct the time series of $\mathrm{BC}$ and $\mathrm{OC}$ concentrations, which turned out to span the time period of 1956-2006. Not only do the concentrations of $\mathrm{OC}$ and $\mathrm{BC}$ in the ice core exhibit significant differences between the summer monsoon and non-monsoon seasons, which is likely due to changes in transport pathways and wet removal, but the ratio of OC to $\mathrm{BC}$ also shows a clear seasonal dependence that might be due to seasonal change in contributions from source regions and/or emission sectors. The CAM5 results show a similar seasonal dependence of $\mathrm{BC}$ and $\mathrm{OC}$ deposition onto the glacier.

The MERRA reanalysis products used to drive the CAM5 model simulation show distinct circulation patterns during the summer monsoon (June-September) and non-monsoon (October-May) seasons. Both the circulation patterns (and the associated aerosol transport and wet removal) and seasonal variation of emissions in major source regions influence the seasonal deposition of aerosol at the Zuoqiupu site. The CAM5 simulation with tagged BC regional sources shows that South Asia is the dominant contributor (81\%) to the 10-year mean BC deposition at the Zuoqiupu site during the non-monsoon season, with $14 \%$ from East Asia, while the contribution of East Asia (56\%) is larger than that of South Asia (39\%) during the monsoon season. For the annual mean BC deposition, South Asia $(75 \%)$ is the biggest contributor, followed by East Asia (21\%). 
The annual mean $\mathrm{BC}$ and $\mathrm{OC}$ deposition fluxes into the ice core are also estimated to explore the interannual variations and long-term trends. Results show stable and relatively low BC and OC fluxes from the late 1950s to 1979 , followed by a steady increase through the mid-1990s. A more rapid increase occurred after the minimum in 2002. The BC and OC deposition fluxes in 2006 were 2 and 3 times the respective average before 1980 .

The overall increasing trend in deposition fluxes since 1980 is consistent with the BC and OC emissions in South Asia as the major contributor. Moreover, the increasing trend of the OC / BC ratio since the early 1990s indicates a growth of the contribution of coal combustion and/or biomass burning to the carbonaceous aerosol emissions in the major contributing source regions, which is consistent with the trends in the consumption of coal, oil and biomass in South Asia.

Our offline calculation using the SNICAR model shows a significant increase in radiative forcing induced by the observed BC and OC in snow after 1980, which has implications for the Tibetan glacier melting and availability of water resources in the surrounding regions. More attention to OC is merited because of its non-negligible light absorption and the recent rapid increases evident in the ice-core record.

Acknowledgements. This work was supported by the China National Funds for Distinguished Young Scientists and the National Natural Science Foundation of China, including 41125003, 41101063, and 2009CB723901. H. Wang, Y. Qian and P. J. Rasch were supported by the US Department of Energy (DOE), Office of Science, Biological and Environmental Research as part of the Earth System Modeling program. R. Zhang acknowledges support from the China Scholarship Fund. PNNL is operated for DOE by Battelle Memorial Institute under contract DE-AC05-76RLO1830. The National Center for Atmospheric Research is sponsored by the National Science Foundation. We thank Z. Guo and S. Yang for providing the observations of snow.

Edited by: X. Xu

\section{References}

Andreae, M. O. and Gelencsér, A.: Black carbon or brown carbon? The nature of light-absorbing carbonaceous aerosols, Atmos. Chem. Phys., 6, 3131-3148, doi:10.5194/acp-6-3131-2006, 2006.

Andreae, M. O. and Merlet, P.: Emission of trace gases and aerosols from biomass burning, Global Biogeochem. Cy., 15, 955-966, doi:10.1029/2000GB001382, 2001.

Aoki, T., Kuchiki, K., Niwano, M., Kodama, Y., Hosaka, M., and Tanaka T.: Physically based snow albedo model for calculating broadband albedos and the solar heating profile in snowpack for general circulation models, J. Geophys. Res., 116, D11114, doi:10.1029/2010JD015507, 2011.

Auffhammer, M., Ramanathan, V., and Vincent, J. R.: Integrated model shows that atmospheric brown clouds and greenhouse gases have reduced rice harvests in India, P. Natl. Acad. Sci. USA, 103, 19668-19672, 2006.

Beine, H., Anastasio, C., Esposito, G., Patten, K., Wilkening, E., Domine, F., Voisin, D., Barret, M., Houdier, S., and Hall, S.: Soluble, light-absorbing species in snow at Barrow, Alaska, J. Geophys. Res., 116, D00R05, doi:10.1029/2011JD016181, 2011.

Bond, T. C. and Bergstrom, R. W.: Light absorption by carbonaceous particles: an investigative review, Aerosol. Sci. Tech., 40, 27-67, 2006.

Bond, T. C., Streets, D. G., Yarber, K. F., Nelson, S. M., Woo, J., and Klimont, Z:: A technology based global inventory of black and organic carbon emissions from combustion, J. Geophys. Res., 109, D14203, doi:10.1029/2003JD003697, 2004.

Bond, T. C., Bhardwaj, E., Dong, R., Jogani, R., Jung, S., Roden, C., Street, D. G., and Trautmann, N. M.: Historical emissions of black and organic carbon aerosol from energy-related combustion, 1850-2000, Global Biogeochem. Cy., 21, GB2018, doi:10.1029/2006GB002840, 2007.

BP Group: BP Statistical Review of World Energy June 2009, Report, BP p.l.c., London, UK, 45 pp., 2009.

Cao, J., Wu, F., Chow, J. C., Lee, S. C., Li, Y., Chen, S. W., An, Z. S., Fung, K. K., Watson, J. G., Zhu, C. S., and Liu, S. X.: Characterization and source apportionment of atmospheric organic and elemental carbon during fall and winter of 2003 in Xi' an, China, Atmos. Chem. Phys., 5, 3127-3137, doi:10.5194/acp-5-3127-2005, 2005.

Cao, J., Zhu, C., Chow, J. C., Liu, W., Han, Y., and Watson, J. G.: Stable carbon and oxygen isotopic composition of carbonate in fugitive dust in the Chinese Loess Plateau, Atmos. Environ., 42, 9118-9122, 2008

Cao, J., Tie, X., Xu, B., Zhao, Z., Zhu, C., Li, G., and Liu, S.: Measuring and modeling black carbon (BC) contamination in the SE Tibetan Plateau, J. Atmos. Chem., 67, 45-60, 2010.

Chen, Y. and Bond, T. C.: Light absorption by organic carbon from wood combustion, Atmos. Chem. Phys., 10, 1773-1787, doi:10.5194/acp-10-1773-2010, 2010.

Chow, J. C. and Watson, J. G.: $\mathrm{PM}_{2.5}$ carbonate concentrations at regionally representative interagency monitoring of protected visual environment sites, J. Geophys. Res, 107, 8344, doi:10.1029/2001JD000574, 2002.

Chow, J. C., Watson, J. G., Pritchett, L. C., Pierson, W. R., Frazier, C. A., and Purcell, R. G.: The DRI thermal/optical reflectance carbon analysis system: description, evaluation and applications in US air quality studies, Atmos. Environ., 27, 1185-1201, 1993.

Clarke, A. D. and Noone, K. J.: Soot in the Arctic snowpack: a cause for perturbations in radiative transfer, Atmos. Environ., 19, 2045-2053, 1985.

Cong, Z., Kang, S., and Qin, D.: Seasonal features of aerosol particles recorded in snow from Mt. Qomolangma (Everest) and their environmental implications, J. Environ. Sci., 21, 914-919, 2009.

Cuffey, K. M. and Paterson, W. S. B. (Eds.): The physics of glaciers, Fourth Edition, Academic Press, Burlington, USA, 11-29, 2010.

Dang, C. and Hegg, D. A.: Quantifying light absorption by organic carbon in Western North American snow by serial chemical extractions, J. Geophys. Res. Atmos., 119, 10247-10261, doi:10.1002/2014JD022156, 2014.

Doherty, S. J., Warren, S. G., Grenfell, T. C., Clarke, A. D., and Brandt, R. E.: Light-absorbing impurities in Arctic snow, 
Atmos. Chem. Phys., 10, 11647-11680, doi:10.5194/acp-1011647-2010, 2010.

Ducret, J. and Cachier, H.: Particulate carbon content in rain at various temperate and tropical locations, J. Atmos. Chem., 15, 5567, 1992.

Fernandes, S. D., Trautmann, N. M., Streets, D. G., Roden, C. A., and Bond, T. C.: Global biofuel use, 1850-2000, Global Biogeochem. Cy., 21, GB2019, doi:10.1029/2006GB002836, 2007.

Flanner, M. G. and Zender, C. S.: Snowpack radiative heating: influence on Tibetan Plateau climate, Geophys. Res. Lett., 32, L06501, doi:10.1029/2004GL022076, 2005.

Flanner, M. G. and Zender, C. S.: Linking snowpack microphysics and albedo evolution, J. Geophys. Res., 111, D12208, doi:10.1029/2005JD006834, 2006.

Flanner, M. G., Zender, C. S., Randerson, J. T., and Rasch, P. J.: Present-day climate forcing and response from black carbon in snow, J. Geophys. Res., 112, D11202, doi:10.1029/2006JD008003, 2007.

Flanner, M. G., Zender, C. S., Hess, P. G., Mahowald, N. M., Painter, T. H., Ramanathan, V., and Rasch, P. J.: Springtime warming and reduced snow cover from carbonaceous particles, Atmos. Chem. Phys., 9, 2481-2497, doi:10.5194/acp-9-24812009, 2009.

Gustafsson, Ö, Kruså, M., Zencak, Z., Sheesley, R. J., Granat, L., Engström, E., Praveen, P. S., Rao, P. S. P., Leck, C., and Rodhe, H.: Brown clouds over South Asia: Biomass or fossil fuel combustion?, Science, 323, 495-497, 2009.

Hadley, O. L. and Kirchstetter, T. W.: Black-carbon reduction of snow albedo, Nat. Clim. Change, 2, 437-440, 2012.

Hansen, J. and Nazarenko, L.: Soot climate forcing via snow and ice albedos, P. Natl. Acad. Sci. USA, 101, 423-428, 2004.

Hegg, D. A., Warren, S. G., Grenfell, T. C., Doherty, S. J., Larson, T. V., and Clarke, A. D.: Source attribution of black carbon in snow, Env. Sci. Tech., 43, 4016-4021, doi:10.1021/es803623f, 2009.

Hegg, Dean A., Warren, Stephen G., Grenfell, Thomas C., Sarah J. Doherty, and Clarke, Antony D.: Sources of light-absorbing aerosol in arctic snow and their seasonal variation, Atmos. Chem. Phys., 10, 10923-10938, doi:10.5194/acp-10-10923-2010, 2010.

Heltberg, R., Arndt, T. C., and Sekhar, N. U.: Fuelwood consumption and forest degradation: a household model for domestic energy consumption in rural India, Land Econ., 76, 213-232, 2000.

Hoffer, A., Gelencsér, A., Guyon, P., Kiss, G., Schmid, O., Frank, G. P., Artaxo, P., and Andreae, M. O.: Optical properties of humic-like substances (HULIS) in biomass-burning aerosols, Atmos. Chem. Phys., 6, 3563-3570, doi:10.5194/acp-6-3563-2006, 2006.

IEA: Chapter 9 - Country and regional profiles in the 450 Scenario, in: World Energy Outlook 2009, International Energy Agency, France, 319-362, 2009.

IPCC: Climate Change 2013: The Physical Science Basis, Contribution of Working Group I to the Fourth Assessment Report of the Intergovernmental Panel on Climate Change, edited by: Solomon, S., Qin, D., Manning, M., Chen, Z., Marquis, M., Averyt, K. B., Tignor M., and Miller, H. L., Cambridge University Press, Cambridge, United Kingdom and New York, NY, USA, 996 pp., 2013.

Ito, A. and Penner, J. E.: Historical emissions of carbonaceous aerosols from biomass and fossil fuel burning for the period 1870-2000, Global Biogeochem. Cy., 19, GB2028, doi:10.1029/2004GB002374, 2005.

Jacobson, M. Z.: Strong radiative heating due to the mixing state of black carbon in atmospheric aerosols, Nature, 409, 695-697, 2001.

Kaspari, S. D., Schwikowski, M., Gysel, M., Flanner, M. G., Kang, S., Hou, S., and Mayewski, P. A.: Resent increase in black carbon concentrations from a Mt. Everest ice core spanning 1860-2000 AD, Geophys. Res. Lett., 38, L04703, doi:10.1029/2010GL046096, 2011.

Kaspari, S., Painter, T. H., Gysel, M., Skiles, S. M., and Schwikowski, M.: Seasonal and elevational variations of black carbon and dust in snow and ice in the Solu-Khumbu, Nepal and estimated radiative forcings, Atmos. Chem. Phys., 14, 80898103, doi:10.5194/acp-14-8089-2014, 2014.

Kirchstetter, T. W. and Thatcher, T. L.: Contribution of organic carbon to wood smoke particulate matter absorption of solar radiation, Atmos. Chem. Phys., 12, 6067-6072, doi:10.5194/acp-126067-2012, 2012.

Kirchstetter, T. W., Novakov, T., and Hobbs, P. V.: Evidence that the spectral dependence of light absorption by aerosol is affected by organic carbon, J. Geophys. Res., 109, D21208, doi:10.1029/2004JD004999, 2004.

Lamarque, J.-F., Bond, T. C., Eyring, V., Granier, C., Heil, A., Klimont, Z., Lee, D., Liousse, C., Mieville, A., Owen, B., Schultz, M. G., Shindell, D., Smith, S. J., Stehfest, E., Van Aardenne, J., Cooper, O. R., Kainuma, M., Mahowald, N., McConnell, J. R., Naik, V., Riahi, K., and van Vuuren, D. P.: Historical (1850-2000) gridded anthropogenic and biomass burning emissions of reactive gases and aerosols: methodology and application, Atmos. Chem. Phys., 10, 7017-7039, doi:10.5194/acp10-7017-2010, 2010.

Lin, G., Penner, J. E., Flanner, M. G., Sillman, S., Xu, L., and Zhou, C.: Radiative forcing of organic aerosol in the atmosphere and on snow: Effects of SOA and brown carbon, J. Geophys. Res. Atmos., 119, 7453-7476, doi:10.1002/2013JD021186, 2014.

Liu, X., Easter, R. C., Ghan, S. J., Zaveri, R., Rasch, P., Shi, X., Lamarque, J.-F., Gettelman, A., Morrison, H., Vitt, F., Conley, A., Park, S., Neale, R., Hannay, C., Ekman, A. M. L., Hess, P., Mahowald, N., Collins, W., Iacono, M. J., Bretherton, C. S., Flanner, M. G., and Mitchell, D.: Toward a minimal representation of aerosols in climate models: description and evaluation in the Community Atmosphere Model CAM5, Geosci. Model Dev., 5, 709-739, doi:10.5194/gmd-5-709-2012, 2012.

Lu, Z., Zhang, Q., and Streets, D. G.: Sulfur dioxide and primary carbonaceous aerosol emissions in China and India, 1996-2010, Atmos. Chem. Phys., 11, 9839-9864, doi:10.5194/acp-11-98392011, 2011.

Lu, Z., Streets, D. G., Zhang, Q., and Wang, S.: A novel backtrajectory analysis of the origin of black carbon transported to the Himalayas and Tibetan Plateau during 1996-2010, Geophys. Res. Lett., 39, L01809, doi:10.1029/2011GL049903, 2012.

Ma, P.-L., Rasch, P. J., Wang, H., Zhang, K., Easter, R. C., Tilmes, S., Fast, J. D., Liu, X., Yoon, J.-H., and Lamarque, J.-F.: The role of circulation features on black carbon transport into the Arctic in the Community Atmosphere Model Version 5 (CAM5), J. Geophys. Res.-Atmos., 118, 4657-4669, 2013.

Marinoni, A., Cristofanelli, P., Laj, P., Duchi, R., Calzolari, F., Decesari, S., Sellegri, K., Vuillermoz, E., Verza, G. P., Villani, P., 
and Bonasoni, P.: Aerosol mass and black carbon concentrations, a two year record at NCO-P (5079 m, Southern Himalayas), Atmos. Chem. Phys., 10, 8551-8562, doi:10.5194/acp-10-85512010, 2010.

McConnell, J., Edwards, R. L., Kok, G. L., Flanner, M. G., Zender, C. S., Saltzman, E. S., Banta, J. R., Pasteris, D. R., Carter, M. M., and Kahl, J. D. W.: 20th century industrial black carbon emissions altered Arctic climate forcing, Science, 317, 1381-1384, 2007.

Ménégoz, M., Krinner, G., Balkanski, Y., Boucher, O., Cozic, A., Lim, S., Ginot, P., Laj, P., Gallée, H., Wagnon, P., Marinoni, A., and Jacobi, H. W.: Snow cover sensitivity to black carbon deposition in the Himalayas: from atmospheric and ice core measurements to regional climate simulations, Atmos. Chem. Phys., 14, 4237-4249, doi:10.5194/acp-14-4237-2014, 2014.

Menon, S., Hansen, J., Nazarenko, L., and Luo, Y.: Climate effects of black carbon aerosols in China and India, Science, 297, 22502253, 2002.

Ming, J., Cachier, H., Xiao, C., Qin, D., Kang, S., Hou, S., and $\mathrm{Xu}, \mathrm{J}$.: Black carbon record based on a shallow Himalayan ice core and its climatic implications, Atmos. Chem. Phys., 8, 13431352, doi:10.5194/acp-8-1343-2008, 2008.

Ming, J., Xiao, C., Du, Z., and Yang, X.: An overview of black carbon deposition in High Asia glaciers and its impacts on radiation balance, Adv. Water Resour., 55, 80-87, doi:10.1016/j.advwatres.2012.05.015, 2013.

Neale, R. B., Chen, C.-C., Gettelman, A., Lauritzen, P. H., Park, S., Williamson, D. L., Conley, A. J., Garcia, R., Kinnison, D., Lamarque, J.-F., Marsh, D., Mills, M., Smith, A. K., Tilmes, S., Vitt, F., Cameron-Smith, P., Collins, W. D., Iacono, M. J., Easter, R. C., Ghan, S. J., Liu, X., Rasch, P. J., and Taylor, M. A.: Description of the NCAR Community Atmosphere Model (CAM 5.0), NCAR/TN-486+STR, available at: http://www.cesm.ucar. edu/models/cesm1.0/cam/docs/description/cam5_desc.pdf (last access: 25 November 2014), 2012.

Novakov, T., Andreae, M. O., Gabriel, R., Kirchstetter, T. W., Mayol-Bracero, O. L., and Ramanathan, V.: Origin of carbonaceous aerosols over the tropical Indian Ocean: Biomass burning or fossil fuels, Geophys. Res. Lett., 27, 4061-4064, 2000.

Novakov, T., Ramanathan, V., Hansen, J. E., Kirchstetter, T. W., Sato, M., Sinton, J. E., and Sathaye, J. A.: Large historical changes of fossil-fuel black carbon aerosols, Geophys. Res. Lett., 30, 1324, doi:10.1029/2002GL016345, 2003.

Pachauri, R. K.: The future of India's economic growth: the natural resources and energy dimension, Futures, 36, 703-713, 2004.

Qian, Y., Flanner, M. G., Leung, L. R., and Wang, W.: Sensitivity studies on the impacts of Tibetan Plateau snowpack pollution on the Asian hydrological cycle and monsoon climate, Atmos. Chem. Phys., 11, 1929-1948, doi:10.5194/acp-11-19292011, 2011.

Qian, Y., Wang, H., Zhang, R., Flanner, M. G., and Rasch, P. J.: A Sensitivity Study on Modeling Black Carbon in Snow and its Radiative Forcing over the Arctic and Northern China, Environ. Res. Lett., 9, 064001, doi:10.1088/1748-9326/9/6/064001, 2014.

Qian, Y., Yasunari, T. J., Doherty, S. J., Flanner, M. G., Lau, W. K. M., Ming, J., Wang, H., Wang, M., Warren, S. G., and Zhang, R.: Light-absorbing Particles in Snow and Ice: Measurement and Modeling of Climatic and Hydrological Impact, Adv. Atmos. Sci., 32, 64-91, doi:10.1007/s00376-014-0010-0, 2015.
Rajput, P., Sarin, M., Sharma, D, and Singh, D.: Characteristics and emission budget of carbonaceous species from post-harvest agricultural-waste burning in source region of the Indo-Gangetic Plain, Tellus B, 66, 21026, doi:10.3402/tellusb.v66.21026, 2014.

Ram, K., Sarin, M. M., and Hegde, P.: Long-term record of aerosol optical properties and chemical composition from a high-altitude site (Manora Peak) in Central Himalaya, Atmos. Chem. Phys., 10, 11791-11803, doi:10.5194/acp-10-11791-2010, 2010.

Ramanathan, V. and Carmichael, G.: Global and regional climate changes due to black carbon, Nat. Geosci., 1, 221-227, 2008.

Ramanathan, V., Chung, C., Kim, D., Bettge, T., Buja, L., Kiehl, J. T., Washington, W. M., Fu, Q., Sikka, D. R., and Wild, M.: Atmospheric brown clouds: impacts on South Asian climate and hydrological cycle, P. Natl. Acad. Sci. USA, 102, 5326-5333, 2005.

Ramanathan, V., Ramana, M. V., Roberts, G., Kim, D., Corrigan, C., Chung, C., and Winker, D.: Warming trends in Asia amplified by brown clouds solar absorption, Nature, 448, 575-578, 2007.

Reddy, M. S. and Venkataraman, C.: Inventory of aerosol and sulphur dioxide emissions from India. Part II - biomass combustion, Atmos. Environ., 36, 699-712, 2002.

Revelle, R.: Energy use in rural India, Science, 192, 969-975, 1976.

Rienecker, M. M., Suarez, M. J., Gelaro, R., Todling, R., Bacmeister, J., Liu, E., Bosilovich, M. G., Schubert, S. D., Takacs, L., Kim, G.-K., Bloom, S., Chen, J., Collins, D., Conaty, A., da Silva, A., Gu, W., Joiner, J., Koster, R. D., Lucchesi, R., and Molod, A.: MERRA - NASA's Modern-Era Retrospective Analysis for Research and Applications, J. Clim., 24, 3624-3648, 2011.

Sarka, S., Chokngamwong, R., Cervone, G., Singh, R. P., and Kafatos, M.: Variability of aerosol optical depth and aerosol forcing over India, Adv. Space Res., 37, 2153-2159, 2006.

Sathaye, J. and Tyler, S.: Transitions in household energy use in urban China, India, the Philippines, Thailand, and Hong Kong, Annu. Rev. Energ. Environ., 16, 295-335, 1991.

Stone, E. A., Lough, G. C., Schauer, J. J., Praveen, P. S., Corrigan, C. E, and Ramanathan, V.: Understanding the origin of black carbon in the atmospheric brown cloud over the Indian Ocean, J. Geophys. Res., 112, D22S23, doi:10.1029/2006JD008118, 2007.

Streets, D. G. and Waldhoff, S. T.: Biofuel use in Asia and acidifying emissions, Energy, 23, 1029-1042, 1998.

Tie, X., Wu, D., and Brasseur, G.: Lung cancer mortality and exposure to atmospheric aerosol particles in Guangzhou, China, Atmos. Environ., 43, 2375-2377, 2009.

Venkataraman, C., Habib, G., Eiguren-Fernandez, A., Miguel, A. H., and Friedlander, S. K.: Residential biofuels in South Asia: carbonaceous aerosol emissions and climate impacts, Science, 307, 1454-1456, 2005.

Venkataraman, C., Sagar, A. D., Habib, G., Lam, N., and Smith, K. R.: The Indian National Initiative for advanced biomass cookstoves: the benefits of clean combustion, Energy Sustain. Dev., 14, 63-72, 2010.

Wang, H., Easter, R. C., Rasch, P. J., Wang, M., Liu, X., Ghan, S. J., Qian, Y., Yoon, J.-H., Ma, P.-L., and Vinoj, V.: Sensitivity of remote aerosol distributions to representation of cloud-aerosol interactions in a global climate model, Geosci. Model Dev., 6, 765-782, doi:10.5194/gmd-6-765-2013, 2013. 
Wang, H., Rasch, P. J., Easter, R. C., Singh, B., Zhang, R., Ma, P. L., Qian, Y., and Beagley, N.: Using an explicit emission tagging method in global modeling of source-receptor relationships for black carbon in the Arctic: Variations, Sources and Transport pathways, J. Geophys. Res.-Atmos., 119, 12888-12909, doi:10.1002/2014JD022297, 2014.

Wang, X., Doherty, S. J., and Huang, J.: Black carbon and other light-absorbing impurities in snow across Northern China, J. Geophys. Res. Atmos., 118, 1471-1492, doi:10.1029/2012JD018291, 2013.

Warren, S. G. and Wiscombe, W. J.: A model for the spectral albedo of snow. II: snow containing atmospheric aerosols, J. Atmos. Sci., 37, 2734-2745, 1980.

Wiscombe, W. J. and Warren, S. G.: A model for the spectral albedo of snow. I: Pure snow, J. Atmos. Sci., 37, 2712-2733, 1980.

Xu, B., Cao, J., Hansen, J., Yao, T., Joswiak, D. R., Wang, N.,Wu, G., Wang, M., Zhao, H., Yang, W., Liu, X., and He, J.: Black soot and the survival of Tibetan glaciers, P. Natl. Acad. Sci. USA, 106, 22114-22118, 2009a.
Xu, B., Wang, M., Joswiak, D. R., Cao, J., Yao, T., Wu, G., Yang, W., and Zhao, H.: Deposition of anthropogenic aerosols in a southeastern Tibetan glacier, J. Geophys. Res., 114, D17209, doi:10.1029/2008JD011510, 2009b.

Yang, M., Howell, S. G., Zhuang, J., and Huebert, B. J.: Attribution of aerosol light absorption to black carbon, brown carbon, and dust in China - interpretations of atmospheric measurements during EAST-AIRE, Atmos. Chem. Phys., 9, 2035-2050, doi:10.5194/acp-9-2035-2009, 2009.

Zhao, S., Ming, J., Sun, J., and Xiao, C.: Observation of carbonaceous aerosols during 2006-2009 in Nyainqêntanglha Mountains and the implications for glaciers, Environ. Sci. Pollut. Res., 20, 5827-5838, doi:10.1007/s11356-013-1548-6, 2013.

Zhao, Z., Cao, J., Shen, Z., Xu, B., Chen, L-W. A., Ho, K., Han, Y., Zhu, C., and Liu, S.: Aerosol particles at a high-altitude site on the Southeast Tibetan Plateau, China: implications for pollution transport from South Asia, J. Geophys. Res.-Atmos., 118, 11360-11375, doi:10.1002/jgrd.50599, 2013. 